metrical parallaxes of which are known; about 2,200 are given in Miczaika's list (Astro. Nach., 270, $249 ; 1940$ ) and fifty others elsewhere. The Russell diagram for these stars is compared to the diagram for about 650 normal stars in the vicinity of the Sun, for spectral types between $F 0$ and $M 5$. It appears that the branch corresponding to the main sequence for stars of high velocity is nearly 0.5 magnitude below that of the normal stars. 'The number of giants of both categories is too small to draw any conclusions about them.

\section{Waverley Gold Medal Essay Competition}

The Waverley Gold Medal and $£ 100$ will be awarded for the best essay of about 3,000 words based on some recent scientific research or new development (whether the author's work or not), giving some indication of the scientific background, the experimental results and its potential application in industry. The essay should be written in a form that is clearly intelligible to a scientist engaged in another field or a director of an industrial firm. The essays will be judged for technical content by specialists in that field, for clarity of presentation and style. A second prize of $£ 50$ will also be awarded, and an additional prize, also of $£ 50$, for the best entry from a competitor under thirty years of age on July 31 , 1958. The competition is open only to persons at present engaged in scientific work. Further information can be obtained from the Editor, Research, 4/5 Bell Yard, London, W.C.2. All entries must be received on or before July 31 .

\section{"Natural Gas in Scotland"}

REFERRING to the article under this title in Nature of December 28, p. 1444, Mr. T. S. Ricketts writes : "The British Petroleum Co., Ltd., has pointed out that the Cousland anticline was not discovered by the D'Arcy Exploration Co., Ltd., but is a wellknown feature of the geological maps published by H.M. Geological Survey and has been known for a very long time. It was first tested shortly after the First World War, when a small amount of gas was proved. Most of the present sub-surface knowledge of the Cousland anticline was obtained by test drillings by the D'Arcy Exploration Co. and the Anglo-American Oil Co. during the period 1937-39. It was at this time that the gas accumulation now being used by the Scottish Gas Board was discovered by the D'Arcy Exploration Co. The local crest maximum with the natural gas in it may have an east-to-west long axis, but the anticline runs north and south and not east and west".

\section{University News :}

Belfast

THE following appointments to supernumerary lectureships have recently been made in The Queen's University of Belfast : R. H. Buchanan (geography); J. F. Gracey and W. A. M. Gordon (veterinary science); J. Patton (agricultural bacteriology); Dr. C. E. Wright (plant genetics and plant breeding); Dr. A. M. Raven (agricultural chemistry); and Dr. A. G. Smith (botany). Dr. J. L. Douce has been appointed lecturer in electrical engineering.

London

Dr. Lanstre Cromare, lecturer in organic chemistry at the Imperial College of Science and Technology, has been appointed to the University readership in organic chemistry tenable at King's College.

\section{Announcements}

The National Institute of Industrial Psychology has appointed Mr. J. D. Handyside to the post of controller of research, with effect from April 1.

Dr. Ethelwynn Trewavas has been appointed a deputy keeper in the Department of Zoology, British Museum (Natural History). She has been a member of the scientific staff of the Museum since 1935 and is a leading taxonomic ichthyologist, her special study being freshwater fishes.

Mr. J. D. Auston, a well-known Norfolk farmer, has been appointed a member of the Agricultural Research Council, to fill a vacancy on the Council. Mr. David Lowe, a member of the Council since 1954, has been appointed deputy chairmen in succession to Prof. S. J. Watson ; Prof. Watson will continue to serve as a member of the Council and as chairman of the Council's Standing Committee on Research affecting Plants and Soils.

THE Physical Society is holding a conference on "Spectroscopy of Solids" at the Royal Radar Establishment, Malvern, on May 28 and 29. Further information can be obtained from the Secretary, Physical Society, 1 Lowther Gardens, Prince Consort Road, London, S.W.7.

THE eleventh Brookhaven symposium in biology will be on "The Photochemical Apparstus: its Structure and Function". It is sponsored by the Biology Department, Brookhaven National Laboratory, Associated Universities, Inc., Upton, New York, and will be held during June 16-18. Further information can be obtained from Dr. R. C. Fuller at the above address.

The seventeenth meeting of the European Fed. eration of Chemical Engineering will be a joint symposium on "The Organization of Chemical Engineering Projects". It will be held at Olympia, London, during June 24-26. Further information can be obtained from the Institution of Chemical Engineers, 16 Belgrave Square, London, S.W.1.

A SYMPosrum on "Continuous Cultivation of Micro-organisms", sponsored by the Institute of Biology of the Czechoslovak Academy of Sciences, will be held during June 23-28 in Prague. The symposium will deal with some theoretical aspects of continuous cultivation and the possibilities of the practical applications of this method. Further information can be obtained from Academician $I$. Málek, Institute of Biology, Czechoslovak Academy of Soiences, Na cvičišti 2, Praha 6, Czechoslovakia.

Dundee Technical College offers two one-week apecial summer programmes to bring information on electronic data processing methods and developments to those who are or may be involved in selecting, programming, operating or managing electronic computers. These are "Electronic Computers and Business Problems", to be held during June 23-27, and "Developments in Electronic Data Processing for Business", to be held during June 30-July 4. Both programmes will be directly supervised by Dr. Robert H. Gregory, professor of accounting, Massechusetts Institute of Technology, assisted by Dr. Stenley Gill, head of the Computing Research Group, Ferranti, Ltd., England. Further information can be obtained from the Head of the Department of Management Studies, Dundee Technical College, 40 Bell Street, Dundee. 